\title{
Pemodelan Spatial Error Model (SEM) Untuk Mengidentifikasi Indeks Pembangunan Manusia di Provinsi Maluku Tahun 2016
}

\author{
Fauzan Samallo \\ Jurusan Matematika Fakultas MIPA Universitas Pattimura, Ambon \\ fazhvan@gmail.com \\ Yopi Andry Lesnussa \\ Jurusan Matematika Fakultas MIPA Universitas Pattimura, Ambon \\ yopi_a_lesnussa@yahoo.com \\ Abraham Z. Wattimena \\ Jurusan Matematika Fakultas MIPA Universitas Pattimura, Ambon \\ az.wattimena@staff.unpatti.ac.id \\ Muhammad Yahya Matdoan \\ Jurusan Matematika Fakultas MIPA Universitas Pattimura, Ambon \\ keepyahya@gmail.com
}

\begin{abstract}
Human Development Index (HDI) is a quality measure that can be used to determine the quality of human development that has been achieved. HDI is a composite index that composed of 3 components, such as: Length of life measured by life expectancy at birth, Education measured by average school duration and expectations school duration and standard of living measured by Purchasing Power Parity (PPP) in rupiah. The model used in this research is Spatial Error Model (SEM) to identify Influence of Variables X on IPM value and pattern of HDI distribution in a region with Ordinary Linear Square (OLS) parameter estimates. From the map thematic data that obtained, it can be seen that the pattern of the spread of Human Development Index (HDI) in Maluku Province has no effect on the distance of a region. There is a correlation between the components of HDI compilers to the HDI value in Maluku Province, because there is a spatial dependency on the dependent variable. Lambda value coefficient which is negative and significant at $\alpha=10 \%$ indicates that there is no correlation of HDI value in a region with other adjacent area. Also indicated by spatial residuals in adjacent areas do not have the same characteristics.
\end{abstract}

Keywords: Human Development Index, Ordinary Linier Square, Spatial Error Model.

\section{Pendahuluan}

Indeks Pembangunan Manusia (IPM) atau Human Development Index (HDI) merupakan salah satu ukuran kualitas yang dapat digunakan untuk mengetahui sejauh mana kualitas pembangunan manusia yang telah berhasil dicapai. IPM merupakan 
indeks komposit yang diharapkan mampu mencerminkan perkembangan kinerja pembangunan manusia di suatu daerah. Pembangunan manusia memperkenalkan konsep yang lebih luas dan lebih komprehensif dan mencakup semua pilihan yang dimiliki oleh manusia di semua golongan masyarakat pada semua tahap pembangunan (UNDP, 2014).

Upaya untuk menghitung indeks-indeks pembangunan manusia sampai ke tingkat kabupaten/kota sangat penting karena proses desentralisasi (otonomi daerah) yang sedang berjalan di Indonesia. Hal ini, akan menyerahkan sebagian besar proses pembangunan kepada pemerintah daerah dan masyarakat lokal, yang diharapkan lebih memahami tentang kondisi daerah setempat serta didukung oleh data-data yang lebih memadai untuk kabupaten/kota yang bersangkutan (BPS, 2016).

Hasil pengukuran IPM di berbagai provinsi khususnya Maluku biasanya ditampilkan dalam bentuk tabel. Metode operasional yang ada sekarang ini sebagian besar belum menggunakan pendekatan spasial sebagai perangkat analisis obyek, sehingga belum dapat memberikan gambaran pola penyebaran IPM. Untuk mengatasi permasalahan tersebut, digunakan suatu metode pendekatan spasial yang memungkinkan pengukuran IPM ditampilkan dalam bentuk visualisasi untuk memberikan informasi yang lebih mudah dipahami dan dianalisis. Visualisasi dalam bentuk peta diharapkan dapat memberikan gambaran kecenderungan spasial yang lebih baik untuk analisis spasial dalam melihat pola spasial dari IPM (Ananta, 2013). Metode spasial merupakan metode untuk mendapatkan informasi pengamatan yang dipengaruhi oleh efek ruang atau lokasi. Efek spasial sering terjadi antara satu wilayah dengan wilayah yang lain atau pengamatan di suatu lokasi seringkali bergantung pada pengamatan di lokasi lain yang berdekatan (Anselin, 1988).

Pada penelitian ini menggunakan Spatial Error Model (SEM) untuk meneliti tentang komponen-komponen penyusun IPM dan seberapa besar komponen pendukung IPM dapat mempengaruhi tingkat IPM di Propinsi Maluku. Model SEM dipilih karena dinilai cocok untuk permasalahan karateristik wilayah (area) yang ada di Propinsi Maluku. Karena karakteristik daerah yang beragam satu sama lainnya, perlu dirumuskan dalam pembuatan suatu model. Oleh sebab itu, penggunaan model SEM diharapkan mampu menghasilkan model IPM, sehingga dapat memberikan informasi serta masukan yang positif bagi pemerintah dalam upaya peningkatan IPM di Maluku.

\section{Metode Penelitian}

Data dalam penelitian ini mencakup data nilai IPM dan komponen-komponen IPM di Provinsi Maluku. Data yang digunakan dalam penelitian adalah data sekunder yang diperoleh dari BPS (Badan Pusat Statistik) Provinsi Maluku tahun 2016. 
Variabel yang digunakan dalam penelitian ini ada lima variabel, dimana lima variabel ini merupakan faktor yang mempengaruhi Indeks Pembangunan Manusia di Provinsi Maluku. Variabel yang terdiri dari satu variabel dependen dan empat varibel independen dengan rincian sebagai berikut: (BPS, 2016)

1. Variabel dependen (Y) yaitu nilai IPM tiap kabupaten/kota di Maluku.

2. Variabel independen $(\mathrm{X})$ yaitu komponen-komponen penyusun IPM di Propinsi Maluku. Variabelnya meliputi:

$\mathbf{X}_{\mathbf{1}}$ : Angka Harapan Hidup (AHH)

$\mathbf{X}_{2}$ : Harapan Lama Sekolah (HLS)

$\mathbf{X}_{\mathbf{3}}$ : Rata-rata Lama Sekolah (RLS)

$\mathbf{X}_{\mathbf{4}}$ : Kemampuan Daya Beli (KDB)

Adapun prosedur penelitian yang dilakukan adalah sebagai berikut (Arbia, G. 2006):

1. Melakukan identifikasi pola hubungan faktor - faktor penyebab IPM (variabel bebas) terhadap IPM (variabel respon).

2. Melakukan pemodelan regresi dengan metode Ordinary Least Square (OLS).

3. Identifikasi tentang keberadaan efek spasial dalam SEM dengan menggunakan uji kebebasan residual.

4. Menganalisis model SEM dengan tahapan sebagai berikut :

a. Menentukan matriks pembobot spasial dengan metode Queen Contiguity

b. Melakukan estimasi parameter, pengujian signifikansi parameter dan uji asumsi regresi dari model SEM yang terbentuk.

$$
Y=X \beta+\lambda W u+\varepsilon
$$

c. Menginterpretasikan model dan membuat kesimpulan dari hasil yang diperoleh.

\section{Hasil dan Pembahasan}

Penelitian ini menggunakan data IPM kabupaten/kota di Provinsi Maluku tahun 2016, dengan komponen-komponen penyusun IPM yaitu Angka harapan hidup (AHH), Harapan lama sekolah (HLS), Rata-rata lama sekolah (RLS) dan Kemampuan daya beli (KDB) seperti pada Tabel 1. 
Tabel 1. Data IPM Kabupaten/Kota Provinsi Maluku Tahun 2016

\begin{tabular}{|c|l|c|r|r|r|r|}
\hline No & \multicolumn{1}{|c|}{ Kabupaten/Kota } & IPM & \multicolumn{1}{c|}{ AHH } & \multicolumn{1}{c|}{ HLS } & \multicolumn{1}{c|}{ RLS } & \multicolumn{1}{c|}{ KDB } \\
\hline 1 & Maluku Tenggara Barat & 61,12 & 62,93 & 12,25 & 8,99 & 5,901 \\
\hline 2 & Maluku Tenggara & 64,2 & 64,45 & 12,4 & 9,17 & 7,063 \\
\hline 3 & Maluku Tengah & 69,54 & 65,93 & 13,77 & 9,18 & 9,672 \\
\hline 4 & Buru & 66,63 & 65,82 & 12,52 & 7,67 & 9,806 \\
\hline 5 & Kepulauan Aru & 61,32 & 62,16 & 11,41 & 8,39 & 7,08 \\
\hline 6 & Seram Bagian Barat & 63,76 & 60,72 & 13,24 & 8,43 & 8,121 \\
\hline 7 & Seram Bagian Timur & 61,15 & 58,32 & 11,99 & 7,53 & 8,848 \\
\hline 8 & Maluku Barat daya & 59,43 & 61,37 & 11,78 & 7,85 & 6,298 \\
\hline 9 & Buru Selatan & 62,19 & 65,6 & 12,22 & 6,96 & 7,175 \\
\hline 10 & Kota Ambon & 79,55 & 69,74 & 15,9 & 11,64 & 13,497 \\
\hline 11 & Kota Tual & 65,64 & 64,33 & 13,87 & 9,76 & 6,803 \\
\hline
\end{tabular}

\section{Deskripsi Pola Penyebaran IPM dan Komponen-Komponen Penyusun IPM Di Provinsi Maluku}

Pada penelitian ini angka yang menunjukkan tingginya nilai dari setiap variabel dikelompokkan menjadi lima kategori yaitu kategori sangat rendah, rendah, sedang, tinggi, dan sangat tinggi. Yang ditandai pada peta dengan warna yang paling mencolok merupakan daerah yang memiliki kategori sangat tinggi hingga warna yang paling pudar merupakan daerah dengan kategori sangat rendah. Hal ini dilakukan agar dapat memudahkan dalam mendeskripsikan setiap variabel penelitian. Berikut ini hasil pemetaan pola penyebaran IPM dan komponen-komponennya yang digunakan dalam penelitian.

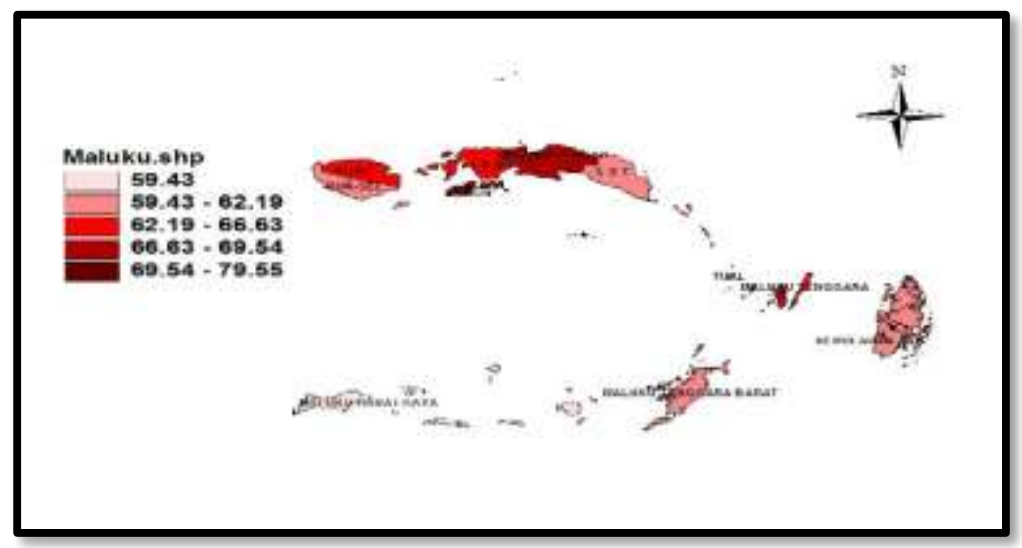

Gambar 1. Persebaran IPM Menurut Kabupaten/Kota di Provinsi Maluku Tahun 2016 
Berdasarkan Gambar 1 diketahui bahwa kabupaten/kota dengan persentase IPM tertinggi berkisar antara 69,54\% - 79,55\% adalah Kota Ambon (79,55\%). Sedangkan kabupaten/kota dengan persentase paling rendah yaitu Maluku Barat Daya (59,43\%).

Berdasarkan Gambar 2 diperoleh kabupaten/kota yang memiliki Angka Harapan Hidup (AHH) tergolong tinggi adalah Kota Ambon dengan nilai 69,74 per tahun. Sedangkan kabupaten/kota dengan AHH yang tergolong sangat rendah yaitu Kabupaten Seram Bagian Timur (58,33 per tahun).

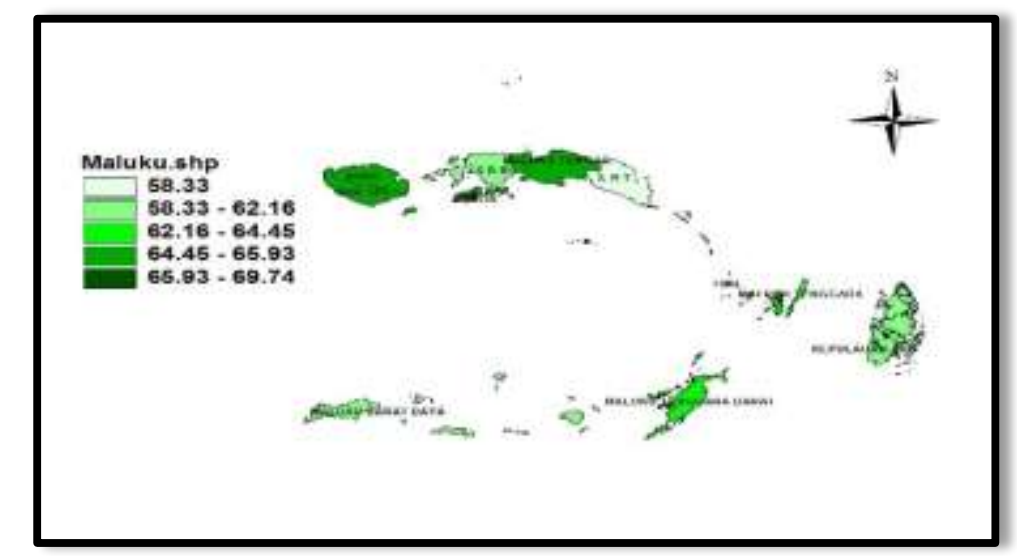

Gambar 2. Persebaran AHH Menurut Kabupaten/Kota di Provinsi Maluku Tahun 2016

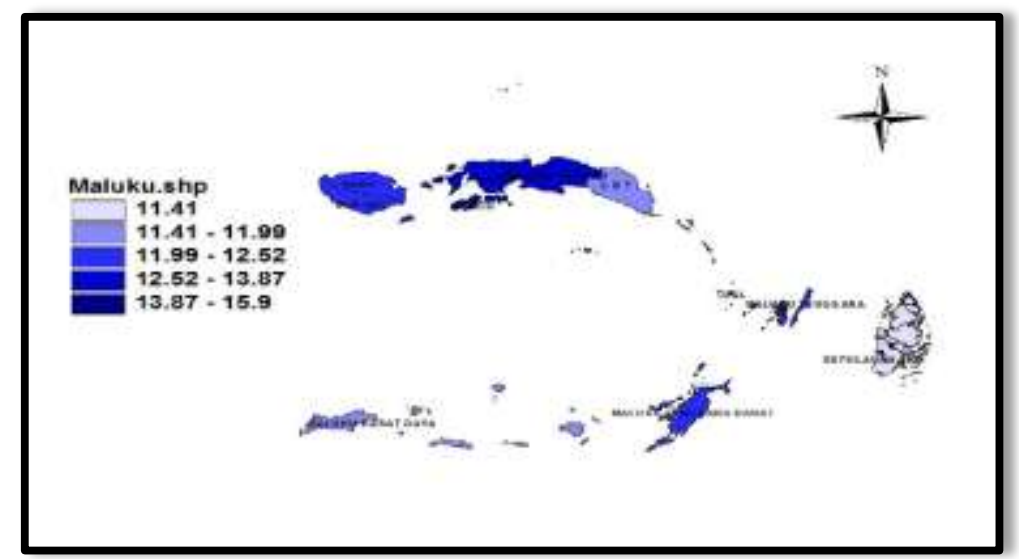

Gambar 3. Persebaran HLS Menurut Kabupaten/Kota di Provinsi Maluku tahun 2016

Berdasarkan Gambar 3 diperoleh kabupaten/kota yang memiliki Persentase Harapan Lama Sekolah (HLS) tertinggi adalah Kota Ambon (15,9\%). Sedangkan kabupaten dengan persentase HLS tergolong sangat rendah adalah Kabupten Kepulauan Aru $(11,41 \%)$. 


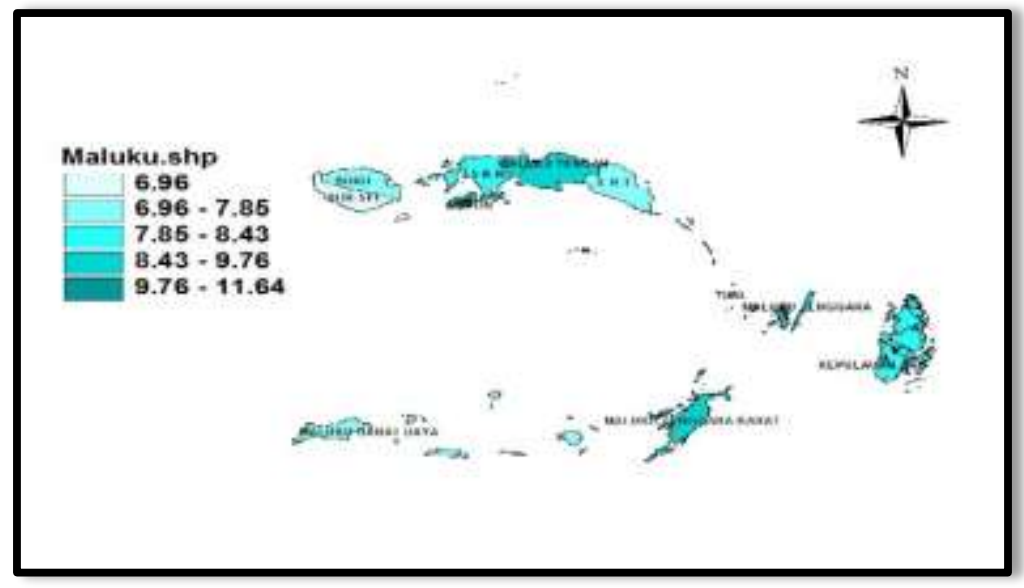

Gambar 4. Persebaran RLS Menurut Kabupaten/Kota di Provinsi Maluku tahun 2016

Berdasarkan Gambar 4 diperoleh kabupaten/kota yang memiliki persentase Ratarata Lama Sekolah (RLS) yang tergolong sangat tinggi yaitu pada Kota Ambon $(11,64 \%)$. Sedangkan Kabupaten dengan persentase yang tergolong sangat rendah yaitu pada Kabupten Buru Selatan (6,96\%).

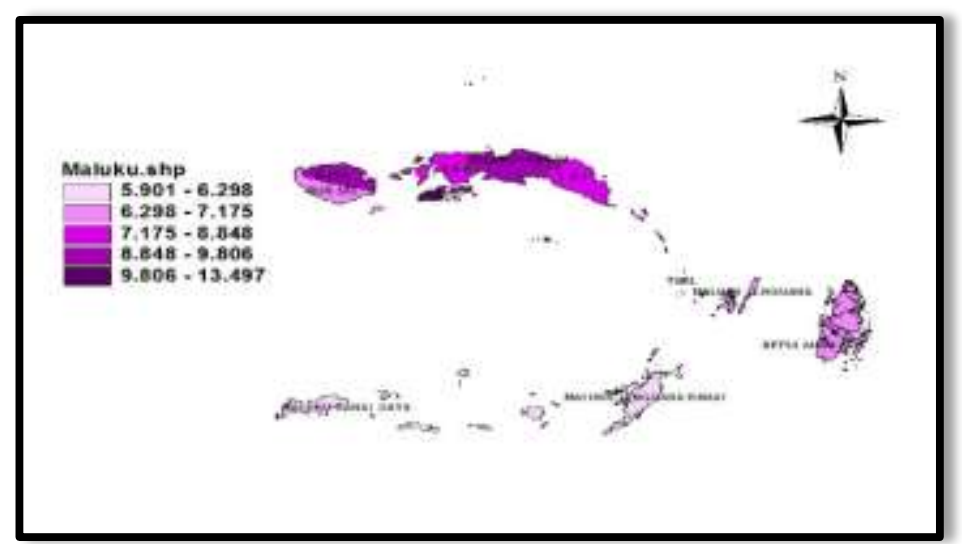

Gambar 5. Persebaran KDB Menurut Kabupaten/Kota di Provinsi Maluku tahun 2016

Berdasarkan Gambar 5 diperoleh kabupaten/kota yang memiliki Kemampuan Daya Beli (KDB) tertinggi yaitu Kota Ambon (Rp 13.497.000,00). Sedangkan terendah pada Kabupaten Maluku Tenggara Barat (Rp 5.901.000,00).

Hubungan antara nilai IPM dengan komponen-komponen penyusunnya ditunjukkan pada Tabel 2 terlihat bahwa P-value dari 4 komponen IPM kurang dari $\alpha=$ $10 \%$. Artinya semua komponen penyusun IPM tersebut memiliki korelasi dengan persentase IPM. 
Tabel 2. Korelasi Persentase IPM (Y) dengan Komponen Penyusunnya (X)

\begin{tabular}{ccc}
\hline Variabel & Korelasi $\mathbf{r}_{\mathbf{x y}}$ & $\mathbf{P}-$ Value \\
\hline AHH $\left(\mathbf{X}_{\mathbf{1}}\right)$ & 0,807 & 0,003 \\
\hline HLS $\left(\mathbf{X}_{\mathbf{2}}\right)$ & 0,929 & 0,000 \\
\hline RLS $\left(\mathbf{X}_{\mathbf{3}}\right)$ & 0,795 & 0,003 \\
\hline KDB $\left(\mathbf{X}_{\mathbf{4}}\right)$ & 0,895 & 0,000 \\
\hline
\end{tabular}

Sebelum melakukan analisis regresi, pendeteksian terhadap multikolinearitas perlu dilakukan. Dapat dilihat pada Tabel 3.

Tabel 3. Pengujian Multikolinieritas

\begin{tabular}{|c|c|}
\hline \multicolumn{2}{|c|}{ Collinearity Statistics } \\
\hline Tolerance & VIF \\
\hline 0,510 & 1,960 \\
\hline 0,153 & 6,536 \\
\hline 0,276 & 3,628 \\
\hline 0,384 & 2,603 \\
\hline
\end{tabular}

Berdasarkan Tabel 3 dapat dilihat bahwa nilai VIF $<10$ dan nilai tolerance $>0,10$ maka dapat dikatakan bahwa tidak terdapat multikolinearitas pada penelitian ini. Oleh karena itu, analisis regresi dapat dilanjutkan dengan tetap menggunakan keempat variabel independen.

\section{Model Regresi}

Pada pemodelan regresi, estimasi parameter dilakukan dengan menggunakan metode Ordinary Least Square (OLS). Dengan pemodelan OLS ini, akan didapatkan parameter-parameter yang signifikan atau tidak, yang berpengaruh terhadap IPM. Hasil regresi OLS disajikan pada Tabel 4 berikut.

Tabel 4. Pengujian Parameter Regresi OLS

\begin{tabular}{ccccc}
\hline Variabel & Koefisien & Std. Error & t - Statistik & P-value \\
\hline Konstanta & 4,45283 & 2,5738 & 1,7300 & 0,13435 \\
\hline AHH & 0,46851 & 0,0487 & 9,6046 & $0,00007^{*}$ \\
\hline HLS & 0,99963 & 0,2163 & 4,6207 & $0,00361^{*}$ \\
\hline RLS & 0,91679 & 0,1598 & 5,7371 & $0,00122^{*}$ \\
\hline KDB & 1,19676 & 0,0799 & 14,9599 & $0,00001^{*}$ \\
\hline $\mathbf{R}^{\mathbf{2}}$ & $99,78 \%$ & & & \\
\hline
\end{tabular}

Ket :*) signifikan pada $\alpha=10 \%$ 
Berdasarkan Tabel 4 diketahui bahwa parameter AHH, HLS, RLS dan KDB mempunyai Nilai signifikan kurang dari $\alpha=10 \%$ artinya pengaruhnya signifikan terhadap nilai IPM pada taraf $\alpha=10 \%$. Nilai AHH, HLS, RLS dan KDB diasumsikan tidak sama dengan dengan nol.

Berdasarkan hasil tersebut maka model OLS yang terbentuk adalah sebagai berikut :

$$
Y_{i}=4,452+0,468 X_{1_{i}}+0,999 X_{2_{i}}+0,916 X_{3_{i}}+1,196 X_{4_{i}}
$$

Keterangan:

$Y_{i} \quad$ : IPM di kabupaten/kota ke-i

$X_{1_{i}}:$ AHH di kabupaten/kota ke-i

$X_{2_{i}}:$ HLS di kabupaten/kota ke-i

$X_{3_{i}}:$ RLS di kabupaten/kota ke-i

$X_{4_{i}}:$ KDB di kabupaten/kota ke-i

Salah satu uji kesesuaian model regresi Ordinary Least Square (OLS) adalah uji kebebasan residual yaitu tidak terjadi autokorelasi, yang diuji dengan menggunakan uji Run test:

Dengan hipotesis yang diajukan sebagai berikut :

$H_{0}$ : Tidak ada autokorelasi antar lokasi

$H_{1}$ : Ada autokorelasi antar lokasi

Uji Run test dilakukan menggunakan bantuan software SPSS. Nilai statistik Run test yang dihasilkan adalah 0,210 >0,05 maka terima $H_{0}$ yang berarti bahwa tidak terdapat autokorelasi antarlokasi untuk data IPM.

\section{Matriks Pembobot}

Dalam sebuah model regresi, sifat-sifat yang dimiliki oleh error tidak lain merupakan sifat-sifat yang dimiliki oleh variabel dependen. Berdasarkan Gambar 1, IPM di Provinsi Maluku nampak berpola mengelompok antara wilayah yang saling berdekatan. Sehingga matriks pembobot spasial yang sesuai dalam penelitian ini adalah matriks pembobot Queen Contiguity. Matriks pembobot ini mensyaratkan adanya pengelompokan wilayah yang memiliki persinggungan antara sisi dan sudut dari wilayah tersebut, dimana $W_{i j}=1$ untuk wilayah yang bersisian (common side) atau titik sudutnya (common vertex) bertemu dengan wilayah yang menjadi perhatian, $W_{i j}=0$ untuk wilayah lainnya.

Matriks pembobot spatial dibuat berdasarkan peta wilayah Provinsi Maluku pada Gambar 1. Berikut ini matriks yang diperoleh berdasarkan Gambar 1, sebagai berikut: 


\begin{tabular}{|c|c|c|c|c|c|c|c|c|c|c|c|}
\hline$R 1$ & $\begin{array}{r}R 1 \\
-\quad 0\end{array}$ & $\begin{array}{r}R 2 \\
1\end{array}$ & $\begin{array}{r}R 3 \\
\mathrm{O}\end{array}$ & $\begin{array}{r}R 4 \\
\quad \text { O }\end{array}$ & $\begin{array}{r}R 5 \\
\quad 1\end{array}$ & $\begin{array}{r}R 6 \\
\text { O }\end{array}$ & $\begin{array}{l}R 7 \\
\quad \mathrm{O}\end{array}$ & $\begin{array}{r}R 8 \\
\quad 1\end{array}$ & $\begin{array}{l}R 9 \\
\quad \text { O }\end{array}$ & $\begin{array}{r}\mathrm{R} 10 \\
\mathrm{O}\end{array}$ & $\begin{array}{r}R 11 \\
\mathrm{O}\end{array}$ \\
\hline$R 2$ & 1 & O & $\mathrm{O}$ & $\mathrm{O}$ & 1 & $\mathrm{O}$ & $\mathrm{O}$ & $\mathrm{O}$ & $\mathrm{O}$ & $\mathrm{O}$ & 1 \\
\hline$R 3$ & $\mathrm{O}$ & $\mathrm{O}$ & $\mathrm{O}$ & $\mathrm{O}$ & $\mathrm{O}$ & 1 & 1 & O & $\mathrm{O}$ & 1 & $\mathrm{O}$ \\
\hline$R 4$ & $\mathrm{O}$ & $\mathrm{O}$ & $\mathrm{O}$ & $\mathrm{O}$ & $\mathrm{O}$ & 1 & $\mathrm{O}$ & $\mathrm{O}$ & 1 & 1 & $\mathrm{O}$ \\
\hline R5 & 1 & 1 & $\mathrm{O}$ & $\mathrm{O}$ & O & $\mathrm{O}$ & $\mathrm{O}$ & $\mathrm{O}$ & O & $\mathrm{O}$ & $\mathrm{O}$ \\
\hline$R 6$ & $\mathrm{O}$ & $\mathrm{O}$ & 1 & 1 & $\mathrm{O}$ & O & $\mathrm{O}$ & O & $\mathrm{O}$ & 1 & $\mathrm{O}$ \\
\hline$R 7$ & O & O & 1 & $\mathrm{O}$ & $\mathrm{O}$ & $\mathrm{O}$ & $\mathrm{O}$ & $\mathrm{O}$ & $\mathrm{O}$ & $\mathrm{O}$ & 1 \\
\hline$R 8$ & 1 & $\mathrm{O}$ & $\mathrm{O}$ & $\mathrm{O}$ & $\mathrm{O}$ & $\mathrm{O}$ & $\mathrm{O}$ & $\mathrm{O}$ & O & $\mathrm{O}$ & $\mathrm{O}$ \\
\hline$R 9$ & $\mathrm{O}$ & $\mathrm{O}$ & $\mathrm{O}$ & 1 & $\mathrm{O}$ & $\mathrm{O}$ & $\mathrm{O}$ & $\mathrm{O}$ & $\mathrm{O}$ & $\mathrm{O}$ & $\mathrm{O}$ \\
\hline$R 10$ & $\mathrm{O}$ & $\mathrm{O}$ & 1 & 1 & $\mathrm{O}$ & 1 & $\mathrm{O}$ & $\mathrm{O}$ & $\mathrm{O}$ & $\mathrm{O}$ & $\mathrm{O}$ \\
\hline$R 11$ & $\mathrm{O}$ & 1 & $\mathrm{O}$ & $\mathrm{O}$ & $\mathrm{O}$ & $\mathrm{O}$ & 1 & $\mathrm{O}$ & $\mathrm{O}$ & $\mathrm{O}$ & $\mathrm{O}$ \\
\hline
\end{tabular}

Selanjutnya matriks tersebut distandarisasi, yaitu jumlah baris sama dengan satu, dengan cara membagi setiap nilai dengan jumlah elemen pada baris tersebut. Matriks pembobot spatial untuk wilayah Kecamatan di Provinsi Maluku adalah sebagai berikut:

$$
\left[\begin{array}{ccccccccccc}
0 & 1 / 3 & 0 & 0 & 1 / 3 & 0 & 0 & 1 / 3 & 0 & 0 & 0 \\
1 / 3 & 0 & 0 & 0 & 1 / 3 & 0 & 0 & 0 & 0 & 0 & 1 / 3 \\
0 & 0 & 0 & 0 & 0 & 1 / 3 & 1 / 3 & 0 & 0 & 1 / 3 & 0 \\
0 & 0 & 0 & 0 & 0 & 1 / 3 & 0 & 0 & 1 / 3 & 1 / 3 & 0 \\
1 / 2 & 1 / 2 & 0 & 0 & 0 & 0 & 0 & 0 & 0 & 0 & 0 \\
0 & 0 & 1 / 3 & 1 / 3 & 0 & 0 & 0 & 0 & 0 & 1 / 3 & 0 \\
0 & 0 & 1 / 2 & 0 & 0 & 0 & 0 & 0 & 0 & 0 & 1 / 2 \\
1 & 0 & 0 & 0 & 0 & 0 & 0 & 0 & 0 & 0 & 0 \\
0 & 0 & 0 & 1 & 0 & 0 & 0 & 0 & 0 & 0 & 0 \\
0 & 0 & 1 / 3 & 1 / 3 & 0 & 1 / 3 & 0 & 0 & 0 & 0 & 0 \\
0 & 1 / 2 & 0 & 0 & 0 & 0 & 1 / 2 & 0 & 0 & 0 & 0
\end{array}\right]
$$

Matriks pembobot spatial tersebut akan digunakan dalam menentukan model SEM untuk mengidentifikasi Indeks Pembangunan Manusia di Provinsi Maluku, sehingga bisa ditentukan ada keterkaitan IPM atau tidak antara suatu wilayah dengan wilayah yang lainnya yang berdekatan.

\section{Spatial Error Model (SEM)}

Selanjutnya dilakukan pemodelan menggunakan SEM. Berikut ini merupakan hasil output dari pemodelan SEM dengan masing-masing nilai parameter pada tingkat signifikansi $10 \%$. 
Tabel 5. Pengujian Parameter SEM

\begin{tabular}{ccccc}
\hline Variabel & Koefisien & Std. Error & $\mathbf{z}$ - Statistik & P- value \\
\hline Konstanta & 6,04849 & 1,68389 & 3,5919 & 0,00033 \\
\hline AHH & 0,42928 & 0,02919 & 14,7066 & 0,00000 \\
\hline HLS & 1,05569 & 0,14325 & 7,3692 & 0,00000 \\
\hline RLS & 0,91727 & 0,09452 & 9,7039 & 0,00000 \\
\hline KDB & 1,22426 & 0,05569 & 21,980 & 0,00000 \\
\hline LAMBDA & $-0,51311$ & 0,22549 & $-2,2754$ & 0,02288 \\
\hline $\mathbf{R}^{2}$ & $99,83 \%$ & & & \\
\hline
\end{tabular}

Berdasarkan output Geoda pada Tabel 5 hasil dari SEM tersebut menunjukkan adanya dependensi spasial pada error. Hal ini nampak dari AHH, HLS, RLS dan KDB memiliki tanda positif serta signifikan pada taraf $\alpha=10 \%$. Selain itu pengaruh variabel AHH, HLS, RLS dan KDB yang signifikan pada taraf $\alpha=10 \%$ berperan penting karena hal ini menunjukan IPM di suatu wilayah dipengaruhi oleh nilai ke 4 variabel tersebut.

Koefisien Lambda bernilai negatif dan signifikan pada taraf $\alpha=10 \%$, menunjukan nilai tidak terdapat keterkaitan nilai IPM pada suatu wilayah dengan wilayah lainnya yang berdekatan. Juga ditunjukan dengan residual spasial pada wilayah yang berdekatan tidak memiliki karakteristik yang sama.

Berdasarkan hasil tersebut maka model SEM yang terbentuk adalah sebagai berikut :

$$
\begin{aligned}
Y_{i}=6,04849 & +0,429289 X_{1_{i}}+1,05569 X_{2_{i}}+0,91727 X_{3_{i}}+1,22426 X_{4_{i}} \\
& +U_{i}
\end{aligned}
$$

dimana

$$
U_{i}=-0,513 \sum_{i, j=1,}^{n} W_{i j} U_{j}+\varepsilon_{i}
$$

Keterangan :

$Y_{i} \quad:$ IPM di kabupaten/kota ke- $i$

$X_{1_{i}}:$ AHH di kabupaten/kota ke- $i$

$X_{2_{i}}:$ HLS di kabupaten/kota ke- $i$

$X_{3_{i}}:$ RLS di kabupaten/kota ke- $i$

$X_{4_{i}}:$ KDB di kabupaten/kota ke- $i$

$W_{i j}$ : matriks penimbang spasial

$U_{i}$ : residual spasial dari kabupaten/kota ke- $i$

$\varepsilon_{i} \quad$ : residual dari kabupaten/kota ke- $i$ 
Model SEM dapat diinterpretasikan bahwa variabel Angka Harapan Hidup (AHH) berpengaruh positif dan signifikan terhadap IPM. Koefisien presentase AHH sebesar 0,429289. Artinya jika persentase $\mathrm{AHH}$ di suatu daerah naik sebanyak 1 persen, maka akan meningkatkan Indeks Pembangunan Manusia (IPM) sebanyak 0,42 per 1000 penduduk.

Adapun pengaruh HLS terhadap IPM adalah juga sama untuk setiap kabupaten/kota dengan elatisitasnya sebesar 1.05569, Artinya jika persentase HLS di suatu daerah naik sebanyak 1 persen, maka akan meningkatkan Indeks Pembangunan Manusia (IPM) sebanyak 1,05 per 1000 penduduk.

Adapun pengaruh RLS terhadap IPM adalah juga sama untuk setiap kabupaten/kota dengan elastisitasnya sebesar 0,91727, Artinya jika persentase AHH di suatu daerah naik sebanyak 1 persen, maka akan meningkatkan Indeks Pembangunan Manusia (IPM) sebanyak 0,91 per 1000 penduduk.

Pengaruh KDB terhadap IPM adalah sama untuk setiap kabupaten/kota dengan elatisitasnya sebesar 1,22426 Artinya jika persentase AHH di suatu daerah naik sebanyak 1 persen, maka akan meningkatkan Indeks Pembangunan Manusia (IPM) sebanyak 1,22 per 1000 penduduk.

\section{Perbandingan Model Regresi OLS dan Model SEM}

Pemilihan model terbaik antara model regresi OLS dan model SEM bertujuan untuk mengetahui model mana yang lebih baik diterapkan pada kasus IPM di Provinsi Maluku. Kriteria kebaikan model yang digunakan adalah dengan membandingkan nilai AIC dari kedua model tersebut. Berikut perbandingan modelnya.

Tabel 6. Nilai AIC Model SEM

\begin{tabular}{|c|c|}
\hline Model & AIC \\
\hline OLS & 10,9671 \\
\hline SEM & 9,2690 \\
\hline
\end{tabular}

Berdasarkan Tabel 6, terlihat bahwa model dengan nilai AIC minimal yaitu pada model SEM. Sehingga model SEM lebih baik digunakan untuk menganalisis data IPM di Maluku dibandingkan dengan model regresi dengan menggunakan metode OLS. Hal ini disebabkan karena model SEM mempertimbangkan efek spasial pada data sementa metode OLS tidak mempertimbangkan efek spasial pada data.

\section{Pengujian dari Asumsi Model SEM}

Model SEM yang terbentuk perlu dilakukan pengujian asumsi, untuk mengetahui kelayakan dan keabsahan dari modelnya diantaranya yaitu asumsi normalitas residual, dan asumsi ada autokorelasi dari residualnya. 
Kenormalan residual dapat diuji secara formal dengan menggunakan Uji Kolmogorov-Smirnov (KS), dengan hipotesis yang diajukan, sebagai berikut:

$H_{0}$ : residual menyebar normal

$H_{1}$ : residual tidak menyebar normal

Kriteria pengambilan keputusan adalah:

Jika $p<\alpha$ maka tolak $H_{0}$ yang berarti bahwa galat dari IPM tidak berdistribusi normal, sebaliknya jika $p>\alpha$ maka terima $H_{0}$ yang berarti bahwa galat dari IPM berdistribusi normal.

Tabel 7. Pengujian Asumsi Normalitas Residual pada Model SEM

\begin{tabular}{|c|c|c|c|}
\hline $\mathrm{N}$ & $\mathrm{KS}$ & $\mathrm{KS}_{\text {tabel }}$ & $\mathrm{P}$ - value \\
\hline 11 & 0,145 & 0,391 & $p>150$ \\
\hline
\end{tabular}

Hasil uji Kolmogorov-Smirnov, yaitu nilai $p>150$ yang berarti bahwa $p>\alpha$ untuk $\alpha$ $=0,05$. Kesimpulannya terima $H_{0}$ yang berarti bahwa galat dari IPM berdistribusi normal.

\section{Asumsi Residual Autokorelasi Spasial}

Asumsi ini menggunakan Uji Durbin Watson dengan hipotesis yang diajukan sebagai berikut:

$H_{0}: \rho=0$ (Tidak ada autokorelasi antar lokasi)

$H_{1} \quad: \rho \neq 0$ (Ada autokorelasi antar lokasi)

Kriteria pengambilan keputusan adalah:

Tolak $H_{0}$ jika $d<d L$ atau $4-d<d L$, terima $H_{0}$ jika sebaliknya.

$d L$ merupakan nilai kritis Durbin-Watson pada tingkat $\alpha$ tertentu.

Nilai Durbin-Watson untuk model SEM diperoleh $d=1,814307$. Sedangkan nilai $d L$ untuk $\alpha=0,05 . \mathrm{n}=11$ dan $\mathrm{K}=4$ adalah 0,4441 . Oleh karena $(1,81430>$ 0,4441) maka terima $H_{0}$ yang berarti bahwa tidak terdapat autokorelasi antar lokasi galat pada model SEM untuk data IPM.

\section{Kesimpulan}

1. Dari data Peta tematik terlihat bahwa pola penyebaran nilai Indeks Pembangunan Manusia (IPM) di Provinsi Maluku tidak berpengaruh pada kedekatan suatu wilayah dengan wilayah lainnya. Hasil dari Output SEM menunjukkan adanya dependensi spasial pada error dan koefisien Lambda bernilai negatif serta signifikan pada taraf $\alpha=10 \%$, menunjukan tidak terdapat 
keterkaitan nilai IPM pada suatu wilayah dengan wilayah lainnya yang berdekatan dan tidak memiliki karakteristik yang sama.

2. Model SEM yang terbentuk untuk memodelkan IPM di Provinsi Maluku pada tahun 2016 adalah:

$$
Y_{i}=6,048+0,429 X_{1_{i}}+1,055 X_{2_{i}}+0,917 X_{3_{i}}+1,224 X_{4_{i}}+U_{i}
$$

\section{Daftar Pustaka}

Ananta, Prayudha. 2013. Determinan Pembangunan Manusia Provinsi Lampung. Tesis. FEB Universitas Lampung.

Anselin, L, 1988, Spatial Econometrics : Methods and Models, Netherlands: Kluwer Academic Publishers.

Arbia, G. 2006. Spatial Econometrics : Statistical Foundations and Applications to Regional Convergence. Berlin : Springer.

Badan Pusat Statistik (BPS) Provinsi Lampung. 2016. Indeks PembangunanManusiaProvinsi Lampung 2016.

Gujarati, Damodar. 2003. Ekonometrika Dasar. Erlangga. Jakarta.

UNDP. (2014). Human Development Report 2014. New York: Oxford University Press. 